\footnotetext{
${ }^{1}$ Leibniz-Centre for Agricultural Landscape (ZALF) Müncheberg, Institute for Land Use Systems and Landscape Ecology, Germany

${ }^{2}$ Leibniz-Centre for Agricultural Landscape (ZALF) Müncheberg, Research Station Paulinenaue, Germany

${ }^{3}$ State Office for Consumer Protection, Agriculture and Land Re-Planning, Groß Kreutz, Germany
}

\title{
Breed-specific classification potentials of sheep in different grassland biotopes
}

\begin{abstract}
There has been an increasing influx from national and international genetic reservoirs into a region that used to be a main breeding area of a merino breed which was consequently reduced to small groups of remaining stocks. Due to the new diversity of breeds it is possible to keep sheep at sites with distinct characteristics in a wide range of different biotopes. As cattle and sheep often share the same feed the latter are mainly kept on sandy and lowyield sites which are typical for Brandenburg. There is a considerable variability of distinctive differences between individual breeds. The present paper describes the specifics of the various breeds to be found in Brandenburg and assesses potentials of their employment in different grassland biotopes. This may provide a basis for further studies into genotype-environment interactions which are of practical and economic relevance for reasonable land use by sheep keeping.
\end{abstract}

Key Words: sheep, breed, grassland, location difference

\section{Zusammenfassung}

Titel der Arbeit: Rassenspezifische Einordnungspotentiale von Schafen in unterschiedliche Grünlandbiotope

In ein ehemaliges Kernzuchtgebiet der Merinorasse sind immer mehr Vertreter aus den nationalen und internationalen Genreservoirs eingeflossen und haben letztendlich diese bis auf Restbestände verdrängt.

Die neu geschaffene Rassenvielfalt ermöglicht den standortangepassten Einsatz des Schafes in einem breiten Biotopspektrum. Hierbei ist zu berücksichtigen, dass diese Tierart oftmals in Futterkonkurrenz zum Rind steht und deshalb schwerpunktmäßig auf für Brandenburg typischen sandigen und damit ertragsarmen Grenzertragsstandorten eingesetzt wird.

Die Variabilität der verschiedenen Merkmalskomplexe ist zwischen den Schafrassen beachtlich. An dieser Stelle wird der Versuch unternommen, rassenspezifische Besonderheiten der in Brandenburg gehaltenen Rassen darzustellen und deren Einsatzpotentiale in unterschiedlichen Grünlandbiotopen abzuschätzen. Die Ausführungen können Ansatzpunkt für die weitere Aufklärung von Genotyp-Umwelt-Interaktionen sein, die für die fachgerechte Landnutzung mit Schafen von praktischer und ökonomischen Relevanz sind.

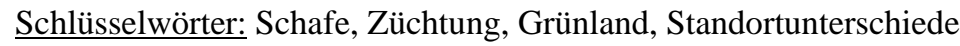

\section{Introduction}

In the federal state of Brandenburg dairy cattle and sheep are traditional grassland users. It has been only over the last ten years that more importance was attached to the keeping of suckling cows and, to a certain extent, also fallow deer.

Now the sheep farmers concentrated their efforts on the production of high-quality lamb meat and on landscape preservation.

In recent years, it has been increasingly realised that sheep keeping considerably contributes to a sustainable management of agricultural areas and to landscape preservation (ZUPP, 2003; BRÜNE and STUMPF, 2004; GROBEREK et al., 2004; 
SEIBERT et al., 2004; SÜß et al., 2004). Policy-making bodies, for instance, recognised with heightened interest the favourable effects produced by sheep keeping on river dikes along the Elbe and its tributaries after the flood in 2002.

Landscape, biotope and dike preservation have developed to become major sources of income for sheep and goat farmers in Brandenburg.

Since 1991, the variety of breeds has significantly expanded in Brandenburg. Sheep were imported from all regions in Germany and from all over Europe. As a consequence, often the site-specific preservation target was not achieved, animal production performance dropped, costs increased and, in some cases, farmers gave up and sheep breeding was discontinued.

This paper, therefore, focuses on the question how the new and richer potential of breeds can be used in a more systematic way. Starting from a characterisation of the various breeds it undertakes to give an overview of the possibilities of their use in terms of the animals' living mass and fleece when kept in different grassland biotopes and under consideration of possible climatic changes.

\section{Natural site conditions and breed structure}

In old documents, Brandenburg was often referred to as the "pounce box of the Holy Roman Empire”. According to agrarian statistics from the beginning of the last century, 42.5 per cent of all soil in the former administrative district of Potsdam was pure sand, the highest percentage in all provinces considered (HESSE, 1914). More recent studies show that soils with very low ground water tables with a field productivity index of under 40 are the dominant soil type here. Accordingly, 76 per cent of all agriculturally productive land belong to the EU category of "disadvantaged areas” (MINISTRY OF NUTRITION, AGRICULTURE AND FORESTRY OF THE FEDERAL STATE OF BRANDENBURG, 1993).

Brandenburg has some 280,000 hectares of grassland, so that almost 20 per cent of its agriculturally productive area is grassland. Pastures of better quality are mostly used by dairy cattle and suckling cows.

Sheep, however, are mostly herded on low-yield and "other" sites. The latter are, to a considerable extent, grassland sites with a very low productivity index, some of which were formerly used as training areas of the armed forces or extensive recultivated area after mining and are registered in cadastral maps as "not agriculturally used areas". It is intended to keep these areas open in the future. Management of the greater part of all areas used for sheep herding must comply with conditions issued by the European Union or the governmental authorities of Brandenburg on nature conservation and extensive land use. Pertinent studies show that soils in Brandenburg are frequently affected by rapid impoverishment processes (BEHLING, 2000; STRITTMATTER, 2001).

It was only after German reunification in 1991 that the consequent adaptation to the EU market caused changes of use and a growing variety of breeds.There are no continuous counts to provide exact information on the total number of animals of specific breeds. Animals registered in flockbooks of the individual breeds (these registered animals represent the highest breeding level of a population) are constantly recorded by the breeders association but the resulting figures are not very precise. The quantitative development of flockbook stocks are shown in Table 1. It must be taken into consideration that the overwhelming majority of sheep farmers work with cross- 
breedings for specific uses. For cross breeding it is common to use ewes that originate from a combination of Merino Mutton sheep on the maternal line and Mutton sheep or German Whiteheaded Land sheep on the paternal line.

Table 1

Development of stocks of female breeding animals (flockbook registrations) of breeds kept in Brandenburg (Entwicklung des Bestandes an weiblichen Zuchttieren (Herdbuchtiere) der in Brandenburg gehaltenen Rassen)

\begin{tabular}{|c|c|c|c|c|c|c|c|}
\hline Year & 1993 & 1995 & 1997 & 1999 & 2001 & 2003 & 2005 \\
\hline \multicolumn{8}{|c|}{ Commercial sheep - Dual-purpose breeds } \\
\hline Merino Mutton sheep & 2651 & 2501 & 1864 & 1330 & 1030 & 292 & 219 \\
\hline Merino Land sheep & 881 & 1259 & 1260 & 1215 & 1430 & 1542 & 1693 \\
\hline Blackheaded Mutton sheep & 335 & 780 & 822 & 1160 & 1190 & 1062 & 1248 \\
\hline Suffolk sheep & 116 & 170 & 286 & 20 & 8 & 5 & 36 \\
\hline Leine sheep & 78 & 101 & 110 & 110 & 128 & 158 & 113 \\
\hline Whiteheaded Mutton sheep & 60 & 70 & 105 & 50 & 40 & 35 & 25 \\
\hline Texel sheep & 6 & 120 & 159 & 145 & 150 & 155 & 145 \\
\hline Romney Marsh sheep & - & 80 & 100 & - & - & - & - \\
\hline Hampshire sheep & - & 10 & 16 & 20 & 22 & 22 & 22 \\
\hline \multicolumn{8}{|l|}{ Triple-purpose } \\
\hline East Friesland Milk sheep & 383 & 259 & 269 & 273 & 258 & 229 & 174 \\
\hline \multicolumn{8}{|l|}{ Land race sheep } \\
\hline Skudden sheep & 285 & 201 & 217 & 255 & 520 & 659 & 901 \\
\hline White Hornless Heath sheep & 140 & 330 & 168 & 30 & 134 & 124 & 102 \\
\hline $\begin{array}{l}\text { Rough-Haired Pomeranian Land } \\
\text { sheep }\end{array}$ & 120 & 110 & 109 & 165 & 161 & 222 & 226 \\
\hline Rhon sheep & 30 & 35 & 35 & 10 & - & 43 & 49 \\
\hline Grey Horned Heath sheep & - & 90 & 212 & 260 & 395 & 447 & 201 \\
\hline Hungarian Prong Horn sheep & - & 50 & 51 & 56 & 66 & 61 & 65 \\
\hline White Horned Heath sheep & - & 30 & 30 & 40 & - & - & - \\
\hline Camaroon sheep & - & 10 & 36 & 65 & 2 & 11 & 11 \\
\hline Bentheim Land sheep & - & - & 160 & 340 & 313 & 408 & 281 \\
\hline Gotland Furred sheep & - & - & 130 & 85 & 112 & 158 & 131 \\
\hline Ouessant sheep & - & - & 3 & 5 & 7 & 7 & 13 \\
\hline Soay sheep & - & - & - & 34 & 12 & 12 & 8 \\
\hline Coburg Fox sheep & - & - & - & 13 & 18 & 48 & 71 \\
\hline Gotland sheep & - & - & - & 6 & 11 & 11 & 6 \\
\hline Romanov sheep & - & - & - & - & - & 5 & - \\
\hline Dorper sheep & - & - & - & - & - & 4 & 4 \\
\hline
\end{tabular}

Stocks of Merino Mutton sheep have undergone dramatic changes over the last 13 years (STRITTMATTER, 2004; FISCHER, 2004). Within this short period, the breed lost its once dominating role despite the fact that efforts to switch breeding from wool producing to meat producing breeds started immediately after 1990. At present, there are only two flockbook-registered flocks where breeding of these animals is continued. Supportive measures should be taken to protect the last remaining stocks. On the other hand, stocks of more productive and more profitable German Whiteheaded Land sheep and Blackheaded Mutton sheep have increased. Initially, Suffolk sheep, an 
internationally relevant mutton sheep breed, showed a promising development. In differing environmental conditions this breed proved its high genetic potential in terms of fattening and meat producing performance. However, stocks dropped abruptly caused by scrapy. Breeding of Romney Marsh (Kent) sheep, another world-wide known breed, was discontinued after a only a few years. A small number of breeders keep some other intensive breeds. Due to high management demands and small flocks their use in maintenance programmes is limited. East Friesland milk sheep, a relatively fastidious breed which produces milk, meat, and wool, is mainly herded for milk production.

The cheese made from the milk is predominantly marketed in and around Berlin.

Extensive breeds are often kept by people without agricultural training or education. The number of Skudde sheep, the physically smallest breed in Germany and threatened with extinction, has considerably grown in recent years thanks to combined development programmes financed by the EU and the state of Brandenburg. It causes no problems to keep this quite undemanding land sheep breed, which produces a small and palatable carcass, on the dry sites in Brandenburg.

As a result of continuous development of stocks, it is this breed and notably mHaired Pomeranian Land sheep, Leine sheep, Grey Horned Heath sheep, and Bentheim Land sheep that are of relevance for the management of specific biotopes.

Apart from performance characteristics and ethological specifics, the origin of the populations concerned, i.e. natural site conditions at their places of origin including such factors as climate, soil characteristics, and fodder as well as the development of certain external characteristics, can be of decisive significance for the assessment of ecological performance potentials. Table 2 gives an overview of the partly very differentiated original conditions of breeds to be found in Brandenburg. It is to be noted that now breeds of all fleece types from merino sheep to hair sheep are kept in Brandenburg (Sources: HAMMOND et al., 1961; MEYNEN et al., 1962; THULKE, 1981; HARING, 1984; VDL, 1999; FISCHER, 2003).

Table 2

Origin and site conditions at the place of origin of breeds kept in Brandenburg with regard to fleece type and breed group (Herkunft und Haltungsbedingungen der Zuchtheimat der in Brandenburg gehaltenen Rassevertreter unter Berücksichtigung von Vliestyp und Rassengruppe)

Breed $\quad$ Place of origin Natural conditions at original site

\begin{tabular}{|c|c|c|}
\hline \multicolumn{3}{|l|}{ 1. Merino sheep } \\
\hline Merino Mutton sheep & $\begin{array}{l}\text { Germany } \\
\text { Saxony, Brandenburg, Saxony-Anhalt, } \\
\text { Lower Saxony }\end{array}$ & $\begin{array}{l}\text { arable cropping sites with dry continental } \\
\text { climate }\end{array}$ \\
\hline German Whiteheaded & Germany & half-dry grassland and higher yield pastures \\
\hline Land sheep & Bavaria, Baden-Württemberg & \\
\hline \multicolumn{3}{|c|}{$\begin{array}{l}\text { 2. Long-woolled mutton breeds } \\
\text { 2.1. English long-woolled mutton breeds }\end{array}$} \\
\hline Romney Marsh & $\begin{array}{l}\text { Britain } \\
\text { Romney-Moore, south-east England }\end{array}$ & $\begin{array}{l}\text { marshland and low-lying forage grassland; } \\
\text { high-rainfall sites }\end{array}$ \\
\hline \multicolumn{3}{|c|}{ 2.2. Sleek-haired marshland breeds } \\
\hline GermanWhiteheaded & Germany & saline foreshore \\
\hline Mutton sheep & $\begin{array}{l}\text { Friesland, Oldenburg, Schleswig- } \\
\text { Holstein }\end{array}$ & $\begin{array}{l}\text { meadows, dikes; maritime climate (relatively } \\
\text { high atmospheric humidity, high precipitation) }\end{array}$ \\
\hline Texel & $\begin{array}{l}\text { The Netherlands } \\
\text { Island of Texel in the North Sea }\end{array}$ & $\begin{array}{l}\text { intensively managed grassland, maritime } \\
\text { climate }\end{array}$ \\
\hline East Friesland Milk sheep & $\begin{array}{l}\text { Germany } \\
\text { North Sea coastal area }\end{array}$ & $\begin{array}{l}\text { marsh pastures, sandy ground moraine; } \\
\text { maritime climate }\end{array}$ \\
\hline
\end{tabular}


Table 2 (continuation)

\begin{tabular}{|c|c|c|}
\hline $\begin{array}{l}\text { Bentheim Land sheep } \\
\text { (marsh sheep x heath } \\
\text { sheep) }\end{array}$ & $\begin{array}{l}\text { Germany } \\
\text { Emsland region }\end{array}$ & $\begin{array}{l}\text { organic wetland, heath and bogs with heath } \\
\text { formation, littoral climate }\end{array}$ \\
\hline \multicolumn{3}{|c|}{ 3. Short-woolled mutton breeds and descents from breed combinations } \\
\hline Hampshire sheep & $\begin{array}{l}\text { Britain } \\
\text { Hampshire, south-west England }\end{array}$ & $\begin{array}{l}\text { thoroughly moistened, forage grassland (lime } \\
\text { soil) }\end{array}$ \\
\hline Suffolk sheep & $\begin{array}{l}\text { Britain } \\
\text { Suffolk, south-east England }\end{array}$ & high-yield arable and grassland areas \\
\hline Blackheaded Mutton sheep & $\begin{array}{l}\text { Germany Westphalia, Schleswig- } \\
\text { Holstein }\end{array}$ & high-yield forage sites, maritime climate \\
\hline \multicolumn{3}{|l|}{$\begin{array}{l}\text { 4. Straight-haired land } \\
\text { sheep }\end{array}$} \\
\hline Rhon sheep & $\begin{array}{l}\text { Germany, Rhon (central German low } \\
\text { mountain range ) }\end{array}$ & $\begin{array}{l}\text { low-yield soils (upland heath, bogs, forest } \\
\text { pastures) wet and cool low-mountain sites }\end{array}$ \\
\hline Coburg Fox sheep & Germany, Norzthern Bavaria & rough and wet low-mountain sites \\
\hline Leine sheep & Germany, southern Lower Saxony & $\begin{array}{l}\text { better soils (i.a. loess and loess clay) sites with } \\
\text { high precipitation }\end{array}$ \\
\hline \multicolumn{3}{|l|}{$\begin{array}{l}\text { 5. Coarse-wool breeds } \\
\text { 5.1. Mixed-woolled land } \\
\text { sheep }\end{array}$} \\
\hline $\begin{array}{l}\text { Rough-Haired Pomeranian } \\
\text { Land sheep }\end{array}$ & $\begin{array}{l}\text { Germany, Pommerania incl. Islands of } \\
\text { Rügen, Usedom and Hiddensee }\end{array}$ & $\begin{array}{l}\text { rolling ground morains, low-yield sandy soils } \\
\text { and fens or wet pastures, relatively high } \\
\text { moisture }\end{array}$ \\
\hline \multicolumn{3}{|l|}{$\begin{array}{l}\text { 5.2. North-European heath } \\
\text { sheep }\end{array}$} \\
\hline Skudde sheep & The Baltic, south-eastern Baltic region & $\begin{array}{l}\text { light soils with poor vegetation, fens, heath } \\
\text { and dry grassland, rough climate }\end{array}$ \\
\hline Grey-Horned Heath sheep & Germany, Lüneburg Heath & $\begin{array}{l}\text { dry, low-nutrient heath sites, sandy and } \\
\text { gravelly soils, relatively high precipitation }\end{array}$ \\
\hline White-Horned Heath sheep & Germany, Weser and Ems region & wet fens and dry heath sites \\
\hline $\begin{array}{l}\text { White Hornless Heath } \\
\text { sheep }\end{array}$ & $\begin{array}{l}\text { Germany, western edge of Lüneburg } \\
\text { Heath }\end{array}$ & wet biotopes and low-yield dry heath \\
\hline Gotland Fur sheep & Sweden & $\begin{array}{l}\text { temperate summers, hard withers with high } \\
\text { snow falls }\end{array}$ \\
\hline Gotland sheep & Sweden, Island of Gotland & low-yield dune heath sites \\
\hline Soay sheep & $\begin{array}{l}\text { Britain, Isle of Soay off north-west } \\
\text { Scotland }\end{array}$ & low feed availibility, rough climate \\
\hline Ouessant sheep & $\begin{array}{l}\text { France, Island of Ouessant off western } \\
\text { Brittany }\end{array}$ & low feed availibility, rough climate \\
\hline \multicolumn{3}{|c|}{ 5.3. South-east European and east-European coarse-woolled breeds } \\
\hline Prong Horn sheep & Hungary & $\begin{array}{l}\text { contionental climate, severe draughts in years } \\
\text { with no summer rains }\end{array}$ \\
\hline Romanow & $\begin{array}{l}\text { Russia, various regions, e.g. Volga } \\
\text { region }\end{array}$ & $\begin{array}{l}\text { low-yield sites with feed featuring high fibre } \\
\text { content, high variations in temperatures, cold } \\
\text { winters }\end{array}$ \\
\hline \multicolumn{3}{|l|}{ 6. Hair sheep } \\
\hline Camaroon sheep & western Africa & $\begin{array}{l}\text { equatorial region with Atlantic and continental } \\
\text { climate }\end{array}$ \\
\hline Dorper & southern Africa & $\begin{array}{l}\text { rather dry and poor vegetation, continental } \\
\text { climate }\end{array}$ \\
\hline
\end{tabular}

Most commercial breeds originate from regions with high-yield grassland areas and higher precipitation. The north European short-tailed heath sheep mostly come from various low-yield regions with a rather rough and capricious climate. Regions with continental climate are the original habitat of Merino Mutton sheep, Romanov sheep , Hungarian Prong Horn sheep, and hair sheep. 
The capacity to adapt to new environmental conditions apparently varies from breed to breed. Some breeds are capable to cope with a very wide range of conditions, while this range may be rather limited for others. Relevant results and reports are predominantly based on practical experience. Systematic animal ecology studies on relevant genotype-environment interactions are rather rare.

\section{Biotope-related plant yields}

The soil types of grassland areas in Brandenburg are 27.5 per cent sand, 7.5 per cent clay, 10.8 per cent half-bog, and 54.2 per cent bog (MINISTRY OF NUTRITION, AGRICULTURE AND FORESTRY, 1994). The feed quality of grassland crops is largely dependent on plant stand populations and management intensity. Decisive factors in this context are the time and frequency of land use.

Table 3 is based on uniform dates for different sites in Brandenburg that are particularly suitable for sheep keeping in this region.

Table 3

Influence of different sites and plant communities on yield and nutrient concentration under extensive grassland management (Einfluss unterschiedlicher Standorte und Pflanzengesellschaften auf Erträge und Nährstoffkonzentrationen bei extensiver Grünlandbewirtschaftung)

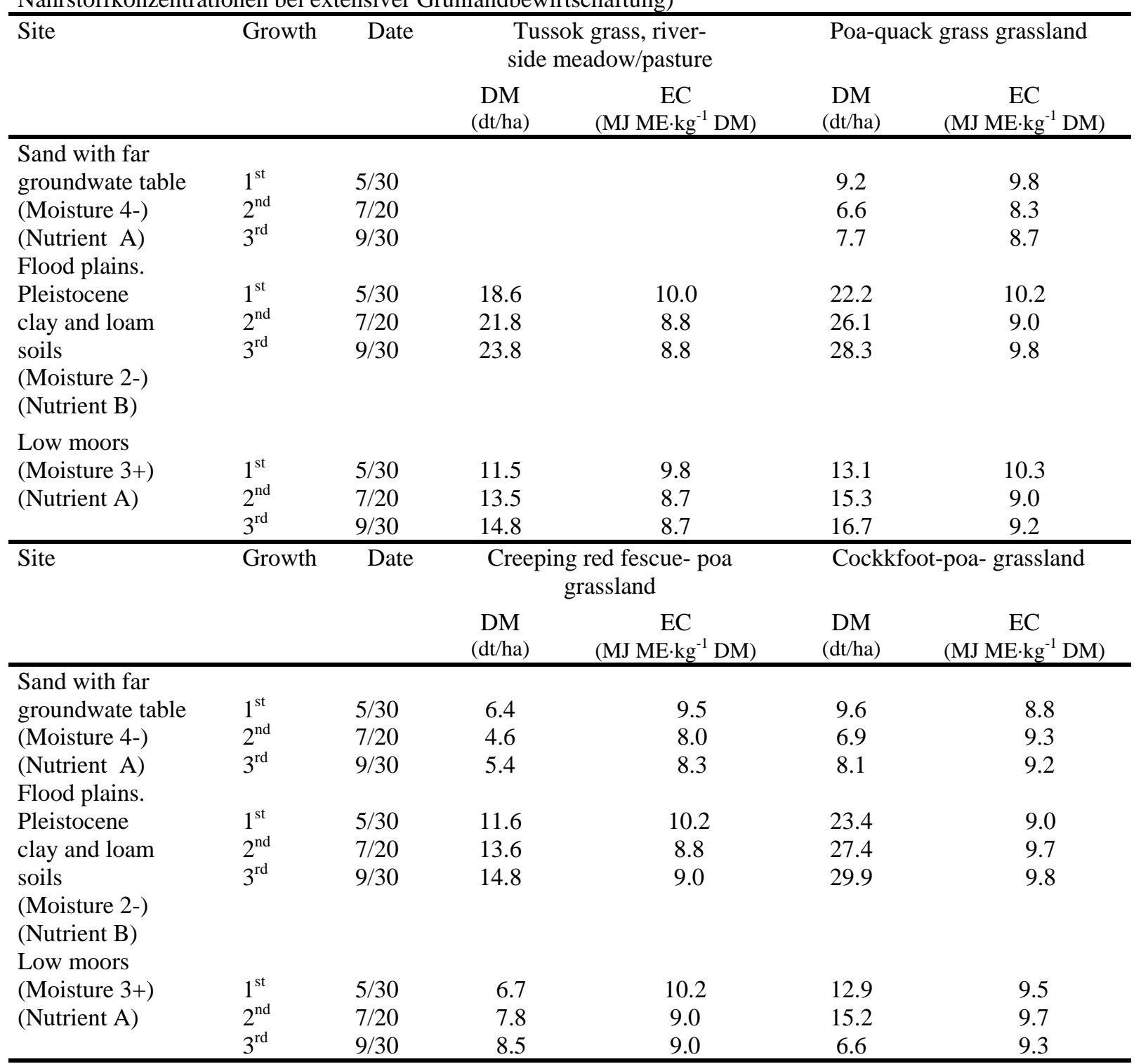


The yield and quality data were supplied from data banks based on results achieved both in experiments and agricultural practice. The values for metabolisable energy (MJ ME.kg $\mathrm{DM}^{-1}$ ) are based on raw nutrient contents derived from feed analyses and estimation equations (WEISSBACH, 1999).

Peak values of metabolisable energy are around 7.8 and $10.3 \mathrm{MJ} \mathrm{ME} \cdot \mathrm{kg} \mathrm{DM}^{-1}$. Yields are lowest on sandy sites with low ground water tables. On sites with such conditions, regrowth takes longer with decreasing feed values. Yields are markedly higher on other sites but they are largely dependent on vegetation forms. The metabolisable energy values in Table 3 are probably still too high as the actual energy contents of grassland crops are distinctly lower than the given values from estimation equations as has been proved by in vivo digestibility trials (HERTWIG and BAECK, 2002; HASSELMANN and FISCHER, 2003; GROBEREK et al., 2004). On the other hand, large-range selective pasturing allows sheep to take up better feed than the stand's average while low-quality herbage remains there as pasture grass leavings (BRÜNE and STUMPF, 2004).

\section{Breed-specific basics for site-related classification of sheep}

There are certain specifics to every breed. They manifest themselves in the living mass, which is closely related to nutritional requirements and thermal balance, in fleece characteristics, digestive physiology, and ethological qualities.

Performance and health decisively depend on the satisfaction of daily dry matter and nutrient requirements. These requirements are, inter alia, related to the living mass of the animal concerned. According to JEROCH et al. (1999), the intake of dry matter of non-pregnant and in-lamb ewes varies between $1.0 \mathrm{~kg}$ and $2.3 \mathrm{~kg}$ per animal and day. It increases by $0.5 \mathrm{~kg}$ in the lactation period. DREPPER and ROHR (1984) reported dry-matter intakes of $2.5 \mathrm{~kg}$ to $2.8 \mathrm{~kg}$ per $100 \mathrm{~kg}$ of sheep. As this source is related to the living mass it is used as a basis on which the intake of dry matter is estimated.

JEROCH et al. (1999) stated weight-related energy and crude protein requirements which are based on data of the Ausschuss für Bedarfsnormen der Gesellschaft für Ernährungsphysiologie GfE (1996) and the Rostock feed evaluation system (2003). According to them, $430 \mathrm{~kJ}$ of metabolisable energy and $4.7 \mathrm{~g}$ of crude protein are required for the maintenance (including mean wool yield and locomotive activities) of $1 \mathrm{~kg}$ of metabolic living mass $\left(\mathrm{W}^{0.75}\right)$ per day. During pregnancy and lactation the maintenance requirement increases by about 30 per cent to 40 per cent, dependent on single or twin births.

Table 4 shows the requirement values of dry matter, energy and crude protein that result from the above equations with estimations being based on the mean living masses of ewes according to the applicable breeding standards. It demonstrates the high degree of variability in the daily requirements of different breeds and indicates both limits and possibilities of their site-related employment.

Seasonal nutrient requirements are largely influenced by reproductive activities. Figure illustrates the daily nutrient requirement of a ewe in an annual cycle. Between winter and spring, the nutrient requirement increases in the last phase of pregnancy and during the four-month nursing period. If high costs of winter feed are to be avoided, conserved feed (notably hay) must meet appropriate standards in terms of quality and quantity. Except a relatively short flushing period to stimulate the intensity of oestrous activities, it is sufficient to meet the maintenance requirement according to living 
mass. In natural reproduction conditions, this period is in the second half of the vegetation period, which is marked by an increase of the crude fibre contents of older green forage.

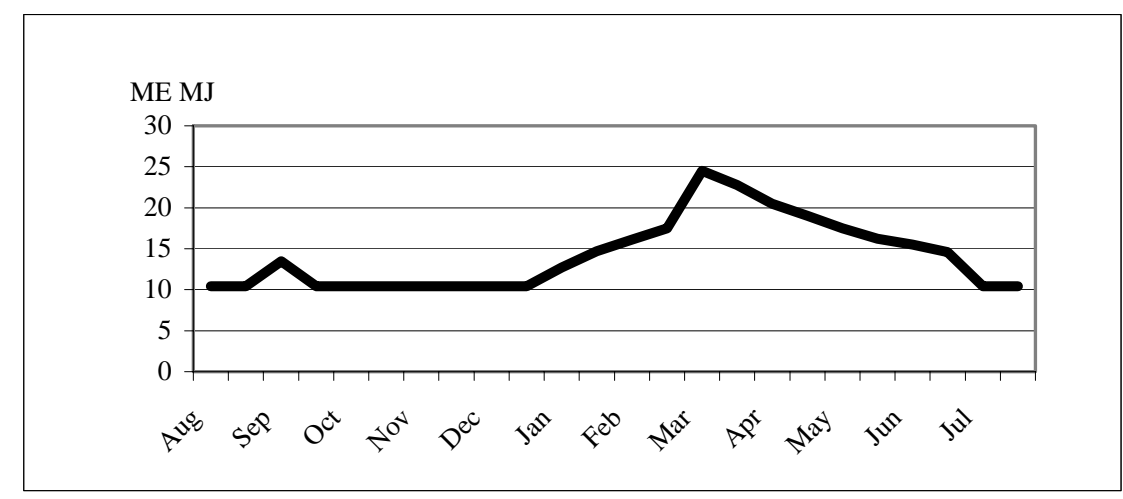

Figure: Energy requirement of ewes related to reproductive stage (70 kg living mass, twins) (mod. after JEROCH et al., 1999) (Energiebedarf von Mutterschafen in Abhängigkeit vom Reproduktionsstadium (70 kg LM, Zwillinge) (mod. nach JEROCH et al., 1999))

Table 4

Estimated dry matter and nutrient requirements of sheep kept in Brandenburg (per ewe and day) (Schätzung des Trockensubstanz- und Nährstoffbedarfs der in Brandenburg gehaltenen Rassen (pro Mutterschaf und Tag))

\begin{tabular}{|c|c|c|c|c|c|}
\hline Breed & $\begin{array}{c}\text { Living } \\
\text { mass } \\
\text { kg }\end{array}$ & $\begin{array}{c}\text { Metabolic living } \\
\text { mass } \\
\mathrm{kg}^{0.75}\end{array}$ & $\begin{array}{c}\text { Dry matter } \\
\text { intake } \\
\mathrm{kg} \cdot \mathrm{d}^{-1}\end{array}$ & $\begin{array}{l}\text { Energy maint. } \\
\text { requirement } \\
\mathrm{MJ} \mathrm{ME} \cdot \mathrm{d}^{-1}\end{array}$ & $\begin{array}{c}\text { Crude protein } \\
\text { requirement } \\
\text { g CP.d }{ }^{-1}\end{array}$ \\
\hline Suffolk & 95 & 30.4 & 2.5 & 13.1 & 143.0 \\
\hline Blackheaded Mutton & 85 & 28.0 & 2.3 & 12.0 & 131.6 \\
\hline Whiteheaded Mutton & 85 & 28.0 & 2.3 & 12.0 & 131.6 \\
\hline East Friesland Milk & 85 & 28.0 & 2.3 & 12.0 & 131.6 \\
\hline Merino Land & 80 & 26.7 & 2.1 & 11.5 & 125.7 \\
\hline Hampshire & 80 & 26.7 & 2.1 & 11.5 & 125.7 \\
\hline Dorper & 78 & 26.2 & 2.1 & 11.3 & 123.4 \\
\hline Merino Mutton & 78 & 26.2 & 2.1 & 11.3 & 123.4 \\
\hline Leine & 78 & 26.2 & 2.1 & 11.3 & 123.4 \\
\hline Texel & 75 & 25.5 & 2.0 & 11.0 & 119.8 \\
\hline Romney Marsh & 65 & 22.9 & 1.7 & 9.8 & 107.6 \\
\hline Bentheim Land & 65 & 22.9 & 1.7 & 9.8 & 107.6 \\
\hline Coburg Fox & 65 & 22.9 & 1.7 & 9.8 & 107.6 \\
\hline Romanow & 65 & 22.9 & 1.7 & 9.8 & 107.6 \\
\hline Rhon & 60 & 21.6 & 1.6 & 9.3 & 101.3 \\
\hline Gotland & 53 & 19.6 & 1.4 & 8.4 & 92.3 \\
\hline $\begin{array}{l}\text { Rough-Haired } \\
\text { Pomeranian Land }\end{array}$ & 53 & 19.5 & 1.4 & 8.4 & 91.7 \\
\hline Gotland Fur & 50 & 18.8 & 1.3 & 8.1 & 88.4 \\
\hline Grey-Horned Heath & 45 & 17.4 & 1.2 & 7.5 & 81.7 \\
\hline White-Horned Heath & 43 & 16.8 & 1.1 & 7.2 & 78.9 \\
\hline Prong Horn & 43 & 16.8 & 1.1 & 7.2 & 78.9 \\
\hline White Hornless Heath & 43 & 16.6 & 1.1 & 7.2 & 78.2 \\
\hline Skudde & 35 & 14.4 & 0.9 & 6.2 & 67.6 \\
\hline Camaroon & 35 & 14.4 & 0.9 & 6.2 & 67.6 \\
\hline Soay & 25 & 11.2 & 0.7 & 4.8 & 52.5 \\
\hline Ouessant & 15 & 7.6 & 0.4 & 3.3 & 35.8 \\
\hline
\end{tabular}


As a consequence, digestibility of organic mass decreases. Digestibility depressions cause a marked reduction of resorbed digestible nutrients. Feed intake is further reduced by the increasing lignification of crude fibre fractionation. The dry matter intake of sheep in relation to living mass and feed fibre contents is calculated in Table 5 .

Table 5

Dry matter intake $(\mathrm{T})$ of sheep used for landscape conservation related to living mass and crude fibre content (XF) of herbage (Trockensubstanzaufnahme (T) von Schafen in der Landschaftspflege in Abhängigkeit von der Lebendmasse und dem Rohfasergehalt (XF) des Weidefutters)

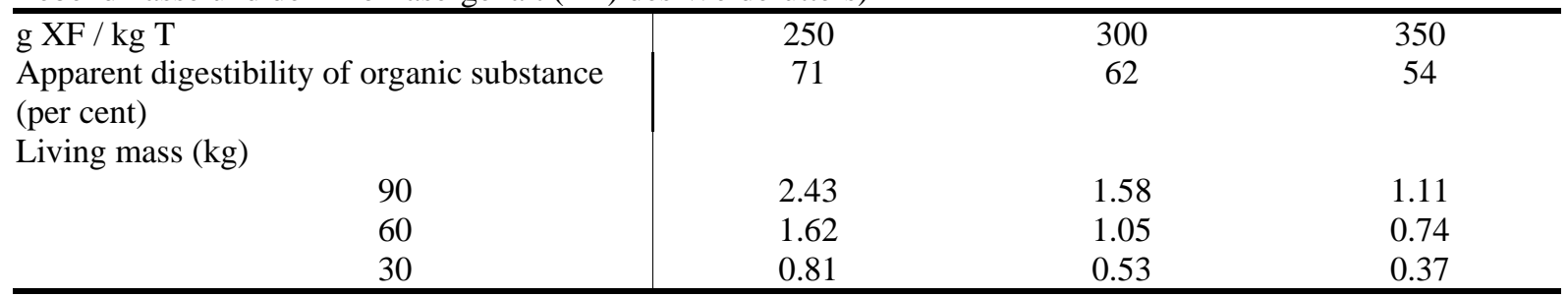

With an estimated possible dry matter intake on marginal sites of 8.5 to $9.0 \mathrm{MJ}$ $\mathrm{ME} / \mathrm{DM}$ the maintenance requirement can hardly be met. Furthermore, it is to be expected that feed intake is reduced by another 10 per cent during high summer dryness. At higher temperatures $\left(>28{ }^{\circ} \mathrm{C}\right)$, the thermo-static regulation of feed intake is a limiting factor. It is on the basis of these factors that different sheep breeds may be categorised according to their feed intake abilities in conditions of extensive grassland management. Table 6 demonstrates a respective categorisation of sheep breeds in Brandenburg. It is to be stressed that the estimation result has to be further supported by scientific studies on the relation between feed intake ability and living mass and breed.

Table 6

Categorisation of breeds related to potential feed intake capacity in conditions of extensive grassland management (Rassenzuordnung entsprechend deren potentiellen Futteraufnahmevermögens im Rahmen der extensiven Grünlandbewirtschaftung)

\begin{tabular}{|c|c|c|}
\hline \multicolumn{3}{|c|}{ Feed intake capacity } \\
\hline good & average & insufficient \\
\hline Leine sheep & Hampshire sheep & Suffolk sheep \\
\hline White Hornless Heath sheep & Dorper sheep & Blackheaded Mutton sheep \\
\hline Grey Horned Heath sheep & Merino Mutton sheep & Whiteheaded Mutton sheep \\
\hline Prong Horn sheep & Texel sheep & East Friesland Milk sheep \\
\hline White Horned Heath sheep & Romney Marsh sheep & Merino Land sheep \\
\hline Skudde sheep & Bentheim Land sheep & Ouessant sheep \\
\hline & Coburg Fox sheep & Soay sheep \\
\hline & Romanov sheep & \\
\hline & Rhon sheep & \\
\hline & Gotland sheep & \\
\hline & Rough-Haired Pomeranian Land & \\
\hline & Gotland Fur sheep & \\
\hline & Camaroon sheep & \\
\hline
\end{tabular}

Due to their high dry matter and nutrient requirements the employment of heavy commercial breeds for purposes of landscape preservation is possible, though limited. They must be offered additional traditionally managed areas in order to limit more cost-intensive supplementary forage. 
The ability of some breeds (e.g. German Heath sheep, Bentheim Country sheep) to take in large quantities of feed with high crude fibre contents (FÖRSTER and KNEIS, 1999) and to increase their rumen volume can be of practical relevance for landscape preservation. As a result, the feed stays longer in the rumen and the digestibility of organic matter increases. This adaptibility is not found with high performance breeds characterised by high growth intensity (JEROCH et al., 1999).

The anticipated climatic change necessitates a different assessment of living mass and fleece structure in the future. There is a direct relationship between feed intake, energy metabolism, performance, and thermal balance. Body and surface are related in inverse proportion. Therefore, small-sized breeds feature a relatively larger exothermal surface than big-sized breeds (Bergmann's rule of size) which means that small animals show a higher heat tolerance. In addition, sheep without or with more coarse mixed-woolled or straight-hair fleece have a higher heat tolerance since such fleeces keep less stagnant air between wool fibres and hair. In a simplified way one may say that, due to the prognosticated climatic changes, more importance will attach to small-framed ewes in the future. Keeping lighter breeds with lower maintenance requirements may be an answer to a temperature-related decrease of grassland plant yields. It would be recommendable, in this connection, to focus breeding efforts on the development of skin pigmentation or coloured and flecked wool. This, however, is at variance with the requirements of the textile industry where white wool is wanted, which is supported by pricing measures. On the other hand, it is known from experience that pure white and unpigmented sheep may suffer from sunburn with negative effects on health and performance when exposed to high solar UV-B radiation (GESCHKE, 1999). Besides, there is also a wide range of possibilities to process coloured wool as a re-growing raw material.

The mating of rams of large-framed and meat-type breeds with small-framed ewes may improve the position on the lamb meat market. Such a development would, however, get along with lower store lamb proceeds per ewe due to reduced performance in terms of fertility performance and fattening and carcass yield, which will not be possible to be completely compensated for (BAEHNE and BEHLING, 1998). In the final analysis, this underlines the importance of overall conditions to be ensured by agricultural policy measures which must take into consideration both market performance and a monetary evaluation of landscape conservation effects of sheep farming in order to guarantee at least an adequate compensation for income losses.

Acknowledgment

With this article we thank the Ministry of Nutrition, Agriculture and Forestry of the Federal State of Brandenburg

\section{References}

BAEHNE, T.; BEHLING, C.:

Aufwandsermittlung der Landschaftspflege mit Schafen und Ziegen auf ausgesuchten Standorten des Landes Brandenburg. Unpublished report commissioned by the Nature Conservation Department of the Brandenburg State Environmental Agency (LUA) and LAGS Eberswalde, 1998

BEHLING, C.:

Konsequenzen für die ökonomische Sicherstellung der Schafhaltung unter den Bedingungen der extensiven Grünlandnutzung. Lecture held at the $3^{\text {rd }}$ expert meeting of the Union of German Sheep Breeders‘ Associations (VDL) on 11 October 2000 
BRÜNE, CH.; STUMPF, T.:

Beweidung von Heide und Sandmagerrasenflächen durch Schafe und Ziegen. Arch. Tierz., Dummerstorf 47 (2004) Special Issue, 18- 24

DREPPER, K.; ROHR, K.:

Grundzüge der Fütterungslehre. Verlag Paul Parey, Hamburg and Berlin, 1984

FISCHER, A.:

Vergleichende Untersuchungen zum Verhalten von Wiederkäuern (Rind und Schaf) auf extensivierten Niedermoorweiden Humboldt University Berlin, Faculty of Agriculture and Horticulture, post-doctoral thesis, 2001

FISCHER, A.:

Deutsche Schafrassen. In: STRITTMATTER, K. (ed.): Schafzucht. Verlag Eugen Ulmer, Stuttgart, 2003

FISCHER, A.:

Merinofleischschaf eine Rasse im Niedergang. Arche Nova, 2004, H 3, S. 15

FÖRSTER, C.; KNEIS, P.:

GESCHKE, C.:

Zucht und Landschaftspflege. Deutsche Schafzucht 91 (1999) 23, 564-567

Verhaltensphysiologische Untersuchungen zur solaren UV-B Belastung von landwirtschaftlichen Nutztieren. Dissertation, Free University Berlin, 1999

GFE:

Ausschuss für Bedarfsnormen der SOCIETY OF NUTRITION PHYSIOLOGY. Energie-Bedarf von Schafen. Proc. Soc. Nutr Physiol., (1996) 5, 149-152

GROBEREK, J.; NIZNIKOWSKI, R.; PFEFFER, E.; RAWA, J.; MARCINEK, M.:

The estimation of nutritive value of pasture grass on wasteland used in sheep production. Arch. Tierz., Dummerstorf 47 (2004) Special Issue, 153-159

HAMMOND, J.; JOHANSSON, I.; HARING, F.:

Handbuch der Tierzüchtung. vol. 3 Rassenkunde, second half-volume, Verlag Paul Parey, Hamburg and Berlin, 1961

HARING, F.:

Schafzucht, Verlag Eugen Ulmer, Stuttgart, 1984

HASSELMANN, L.; FISCHER, A.:

Analyse des Nährstoffgehalts von Weidefutter auf extensiviertem Niedermoor. 115. VDLUFA-meeting, Saarbrücken, congress proceedings, 2003, pp. 83-84

HERTWIG, F.; BAECK, I.:

Veränderungen im Pflanzenbestand und Futterwert bei naturschutzorientierter Bewirtschaftung von Niedermoorgrünland in Nordostdeutschland. Proceedings of the $46^{\text {th }}$ annual meeting of the Grassland and Forage Cropping Working Group, 2002, pp. 45 - 50

HESSE, H.:

Arbeiten der Landwirtschaftskammer für die Provinz Brandenburg, 1914, Heft 43

JEROCH, H.; DROCHNER, W.; SIMON, O.:

Ernährung Landwirtschaftlicher Nutztiere. Verlag Eugen Ulmer, Stuttgart, 1999

MEYNEN, E.; SCHMITHÜSEN, J.; GELLERT, J.; NEEF, E.; MÜLLER-MINY, H.; SCHULTZE, J. H.:

Handbuch der naturräumlichen Gliederung Deutschlands. Federal Agency of Regional Studies and Site Planning Research, own publication, Bad Godesberg, 1962

MINISTRY OF NUTRITION, AGRICULTURE AND FORESTRY.:

Agricultural Report. Ministry of Nutrition, Agriculture and Forestry of the State of Brandenburg, 1993, 1994

MINISTRY OF NUTRITION, AGRICULTURE AND SITE PLANNING:

Annual Agricultural Report of the Federal State of Brandenburg. Ministry of Nutrition, Agriculture and Site Planning of the State of Brandenburg, Potsdam, 2003

ROSTOCK FEED EVALUTION SYSTEM. JENTSCH, W.; CHUDY, A.; BEYER, M.:

Verlag Plexus, Frankfurt/M., 2003

SEIBERT, B.; GAULY, M.; ERHARDT, G.:

Productivity of different sheep breeds in extensive pasture managemaent. Arch. Tierz., Dummerstorf $\mathbf{4 7}$ (2004) Special Issue, 142-152

STRITTMATTER, K.:

Das Verhalten von Schafen verschiedener Rassen bei der Weidenutzung von Rekultivierungsflächen des Bergbaues. Arch. Tierz., Dummerstorf 44 (2001) Special Issue, 224-229

STRITTMATTER, K.:

Die Feinwollrasse Merinofleischschaf in Deutschland - Stand und Probleme. Arch. Tierz., Dummerstorf 47 (2004) Special Issue, 25-35

SÜß, R.; SIERSLEBEN, K.; RÖSLER, H.-J.; DÖRING, L.: 
Analyse der Wirtschaftlichkeit in schafhaltenden Betrieben. Arch. Tierz., Dummerstorf 47 (2004) Special Issue, 135-141

THULKE, H.-G.:

Schafrassen und ihre Bedeutung. In: SCHWARK, H.-J.; JANKOWSKI, ST.; VERESS, L.: Internationales Handbuch der Tierproduktion - Schafe. VEB Deutscher Landwirtschaftsverlag, Berlin, 1981

VDL (UNION OF GERMAN SHEEP BREEDERS` ASSOCIATIONS)

Unsere Landschafe. VDL - Rassenbeschreibung. Deutsche Schafzucht 91 (1999) 14, 349-356

WEISSBACH, F.:

Schätzung der Verdaulichkeit und der Umsetzbaren Energie von Gras und Grasprodukten, Proc. Soc. ZUPP, W.: Nutr. Physiol. 8 (1999), 72

Durch Kreuzung zu marktgerechten Schlachtlämmern. Arch. Tierz., Dummerstorf 46 (2003) Sonderheft, 78-83

Received: 2006-05-18

Accepted: 2007-01-11

Author's addresses

Dr. habil. ANDREAS FISCHER*

Leibniz-Zentrum für Agrarlandschaftsforschung (ZALF) e.V., Institut für Landnutzungssysteme und Landschaftsökologie

Eberswalder Str. 84

15374 MÜNCHEBERG, GERMANY

*Corresponding Author; E-Mail: afischer@zalf.de

Prof. Dr. GISBERT SCHALITZ

Leibniz-Zentrum für Agrarlandschaftsforschung (ZALF) e.V.,

Forschungsstation Landwirtschaft

Gutshof 7

14641 PAULINENAUE, GERMANY

E-Mail: gschalitz@zalf.de

CHRISTOPH BEHLING

Landesamt für Verbraucherschutz, Landwirtschaft und Flurneuordnung Brandenburg

Lehniner Chaussee 1

14550 GROß KREUTZ, GERMANY 